\title{
Morphological and Isozyme Variation in Natural Populations of the Genus Medicago L. Prospected in Northern Algeria
}

\author{
Imane MEDOUKALI, Ines BELLIL, Douadi KHELIFI*
}

\author{
Université Constantine 1, Faculté des Sciences de la Nature et de la Vie, Laboratoire de Génétique Biochimie et Biotechnologies Végétales, 25000 Constantine, \\ Algérie;imane.kako@hotmail.fr;bines07@yahoo.fr;dkhelifi@yahoo.fr(*orrespondingauthor)
}

\begin{abstract}
As part of the evaluation and enhancement of genetic resources, morphological and isozyme variability within and among 169 accessions, representing 14 species of the genus Medicago L. collected in northern Algeria, was assessed using twelve quantitative traits and two enzymatic systems. Phenotype frequencies were scored in six enzyme zones to determine isozyme variability within and among populations. The data analysis resolved a high level of genetic diversity. Ten morphometric characteristics contributed to the discrimination of the species. The relationship between the collection site environment and phenotypic characteristics was also studied. Esterase (EST) enzyme system was more polymorphic than glutamate oxaloacetate transaminase (GOT) system. Were scored 2 zones with 10 bands and 21 phenotypes for GOT (glutamate oxaloacetate transaminase) and 4 zones with 22 bands and 71 phenotypes for EST (esterase) Polymorphism index and Jaccard's genetic distances revealed the existence of a high genetic diversity within and among the studied populations. The annual species $M$. polymorpha presented an intraspecific polymorphism index of 0.57 , which was higher than all other species indices. Clustering of the species based on isozyme markers was in agreement with taxonomic criteria and showed no significant correlation with morphological characteristics. Conservation programs should take into account the level of genetic diversity within and between populations revealed by isozyme markers.
\end{abstract}

Keywords: genetic diversity, isozymes, Medicago L., polymorphism, quantitative traits

\section{Introduction}

The Medicago genus (medics) is part of the Galegoid phylum that includes a number of important legume (Fabaceae) crops such as pea, chickpea, clover and lentil. It consists of approximately 87 annual and perennial species of herbs and shrubs widespread from the Mediterranean to central Asia (Small and Jomphe, 1989; Small, 2010). It includes the widely cultivated major forage crop and weedy species $M$. sativa L. (alfalfa, lucerne) and the legume model species $M$. truncatula Gaertn. (Bell et al., 2001). Medicago has been one of the most widely studied legumes because of numerous agriculturally important and domesticated species (Small, 2010). In addition to alfalfa, which is the most cultivated legume, other species are used as medicine, human food (honey production, sprouts), green manure, sources of industrial enzymes in biotechnology (Lewis et al., 2005), model genomic species (Cannon et al., 2006) and model systems for the study of nitrogen fixation (Bailly et al., 2007). The genus contains a great variety of morphological characteristics (spiny and spineless pods, presence of hairs, corolla colors etc.), of ploidy levels and basic chromosome numbers (Bena et al., 1998). Algeria represents one of the richest zones in genetic diversity and contains 22 annual and perennial Medicago species (Quezel and Santa, 1962). Morphological and agronomic characteristics such as seed and fruit size are often used for estimating genetic variation. Despite criticisms of using these markers, that are usually polygenic and influenced by environmental conditions (Kongkiatngam et al., 1995), they have proven useful in many studies on the genus Medicago L. (Al-Faifi et al., 2013; Bonnin et al., 1996; Bullita et al., 1994; Cherifi et al., 1993; El Hansali et al., 2007; Radwan et al., 1980; Tucak et al., 2008; $\square$ ivković et al., 2012). Isozymes as codominant markers provide a useful clue for the estimation of population structures and phylogenetic relationship (Ferguson and Robertson, 1996; Malaviya et al., 2008) because zymographic patterns reflect directly a particular gene system. It has been well demonstrated that genetic diversity is correlated with genetic distance as measured by allozyme variation (Brown and Weir, 1983). Nevertheless, only a limited number of enzymes can be detected in electrophoresis, which limits their usefulness in estimation of genotypes variability ( $\square$ ivkovic et al., 2012). However, isozymes have been extensively used in the studies of Medicago genetic variation (Bullitta et al., 1994; 
Chandra et al., 2011; Chérifi, 1996; Haddioui et al., 2012; Jenczewski et al., 1999a, 1999b).

Medicago genus is distributed worldwide and grown in highly contrasting environments. This extensive geographical adaptation promotes genetic variation and gives us the opportunity to use diverse gene pools. In this investigation, it was aimed to assess genetic diversity within and among natural populations of the genus Medicago L. collected in Northern Algeria at morphological and enzymatic levels. This will be helpful in directing conservation and breeding programs for the improvement of Medicago species.

\section{Materials and methods}

\section{Plant materials}

The study was conducted on 169 accessions representing 14 species of the genus Medicago L.: $M$. truncatula (29 acc), $M$. polymorpha var. polymorpha (28 acc) and var. vulgaris (28 acc), $M$. ciliaris (19 acc), M. orbicularis (18 acc), M. minima (15 acc), $M$. murex (12 acc), M. italica (5 acc), M. littoralis (5 acc), $M$. rigidula (3 acc), $M$. intertexta (2 acc), $M$. lupulina (2 acc), $M$. sativa (1 acc), $M$. arborea (1 acc) and $M$. arabica (1 acc). These species were collected from 47 different geographic Algerian sites from 15 May to 15 July 2013. The collecting sites extended from the coastal region to the Atlas Tellian mountains, including the coastal plains and the steppic highlands, along a gradient of increasing aridity from North to South. The studied populations cover a wide range of bioclimatic stages ranging from the humid to the arid in Northern Algeria (Fig. 1). The prospected sites were characterized by their altitude (Alt), the classical Emberger's coefficient $(\mathrm{Q} 2)$, the average annual rainfall $(\mathrm{Pm})$, the average of the minimum temperature of the coldest month $(\mathrm{Tm})$ and the average of the maximum temperature of the hottest month (TM) (Table 1). Mature seeds of each individual were extracted from pods, scarified, then sterilized with $3 \%(\mathrm{v} / \mathrm{v})$ sodium hypochlorite solution. Sterile grains were germinated in the dark for 2 days in petri dishes containing $1 \%$ water-agar $(\mathrm{w} / \mathrm{v})$ at room temperature, then kept under normal daylight for 6 days.

\section{Morphological analysis}

Morphological measurements were implemented on only 13 species of the collection. For each accession, twelve quantitative traits related to pod, seed and seedling described by Issolah and

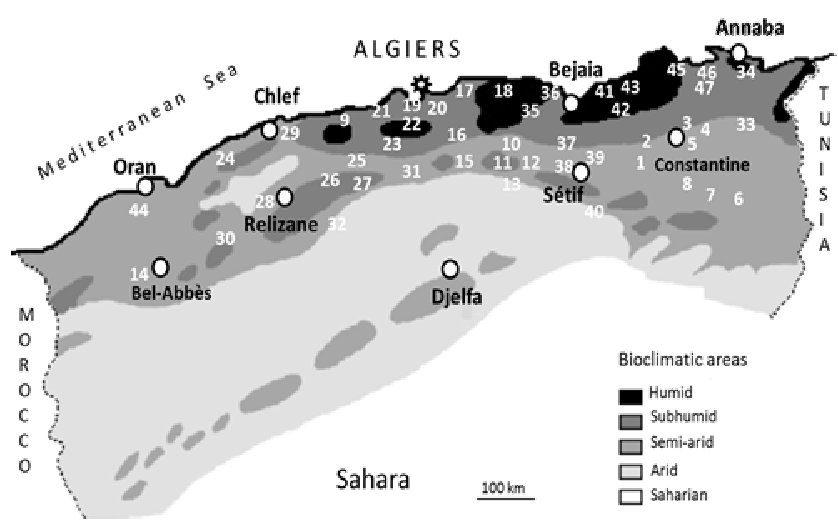

Fig. 1. Map indicating the location of the sampled populations of the genus Medicago L. in relation to bioclimatic stages in northern Algeria
Abdelguerfi (1999) were scored: pod size: length (LP), width (WP); number of seeds per pod (SP); seed size: length (LS), width (WS); weight of 30 pods (WTP); weight of a thousand seeds (WTS) and the ratio weight of seeds/weight of pods (RW); seedling traits: Emergence date of cotyledons (DCOT), length of the first leaf (LFL), breadth of the first leaf (BFL) and Area of the first leaf (AFL=LFL*BFL). DCOT was measured from the moment the seedlings were placed under light. LFL, BFL and AFL were measured after six days of germination. Each trait was scored as a mean value of ten randomly chosen individuals for every accession.

\section{Isozyme analysis}

A total of 169 accessions represented by 14 species were assessed using two enzymatic systems: Esterase (EST, E.C. 3.1.1.-) and glutamate oxaloacetate transaminase (GOT, E.C. 2.6.1.1) (Weeden and Wendel, 1990). Isozymes were extracted from seedling leaves using the procedure of Bendiab et al. (1993). Polyacrylamide gel electrophoresis (PAGE) was performed according to Singh et al. (1991) on $10 \%$ polyacrylamide gels for the analysis of EST, while GOT system required $7 \%$ polyacrylamide gels (Bendiab et al., 1993). The analysis was carried out at $40 \mathrm{~mA}$ for 3 hours at 4 ${ }^{\circ} \mathrm{C}$. Gels were stained according to the methods given by Bendiab et al. (1993).

\section{Data analysis}

The morphological characteristics were analyzed using the principal component analysis (PCA). Mean, standard deviation (s.d.) and coefficient of variation (CV) of the morphological traits for the 13 studied species were computed. The correlation between morphological variability and bioclimate was examined by another PCA including the most important ecological parameters (Alt., Pm, Tm, TM and Q2). Phenetic relationships among species were evaluated by UPGMA (Unweighted PairGroup Method using Arithmetic Averages) cluster analysis based on Euclidean distances. All analyses based on morphological markers were performed using Statistica version 6.0 program.

For each enzyme system, Phenotypic polymorphism for each isozyme locus and species was estimated using the $\mathrm{P}_{\mathrm{j}}$ index utilized by Kahler et al. (1980), Al Mouemar and Gasquez (1983), Warwick and Black (1986) and Bendiab et al. (1993): $P_{j}$ $=\sum_{i=1}^{n} \mathrm{P}_{\mathrm{i}}\left(1-\mathrm{P}_{\mathrm{i}}\right)=1-\sum_{i=1}^{\mathrm{N}} \mathrm{P}_{\mathrm{i}}^{2}$ where $\mathrm{P}_{\mathrm{i}}$ is the frequency of the ith phenotype and $\mathrm{n}$ is the number of phenotypes observed per locus for each species. The weighted average amount of phenotypic polymorphism $\widehat{\mathbf{P}}$ over all observed enzyme zones is given by $\widehat{\mathbf{P}}$ $=\sum_{j=1}^{R}\left(1 / \mathrm{N}_{\mathrm{j}}\right) \mathrm{P}_{\mathrm{j}} / \Sigma_{i}(j=1)^{\mathbf{1}} K \overline{\mathrm{s}}\left(1 / \mathrm{N}_{\mathrm{j}}\right)$, where $\mathrm{N}_{\mathrm{j}}$ is the total number of phenotypes observed (collection wide) per jth locus for $\mathrm{k}$ loci. To estimate the isoenzymatic variation among the species UPGMA dendrogram was constructed based on Jaccard's index (Jaccard, 1908) using XLSTAT version 2014.1.09 software package. The reliability of the generated dendrogram was also tested using SPSS version 20.0 and Statistica version 6.0 Software programs. The correlation between the morphological and isozyme distances was tested with Mantel Z-statistic (Mantel, 1967). 
88

Table 1. Medicago accessions and sampling sites with main bioclimatic parameters used in this study

\begin{tabular}{|c|c|c|c|c|c|c|c|}
\hline $\mathrm{N}^{\circ}$ & Localities & Sample size & Alt & $\mathrm{Pm}$ & $\mathrm{Tm}$ & TM & $\mathrm{Q} 2 *^{*}$ \\
\hline 1 & Oued Athmenia & $5(\mathrm{Mt}, \mathrm{Mpv}, \mathrm{Mc}, \mathrm{Mo}, \mathrm{Marb})$ & 757 & 568 & 2.5 & 31.3 & 67.65 \\
\hline 2 & Bab Trouche & $4(\mathrm{Mt}, \mathrm{Mp}, \mathrm{Mc}, \mathrm{Mmx})$ & 831 & 742 & 4.4 & 31.1 & 95.32 \\
\hline 3 & Beni Hemiden & $6(\mathrm{Mt}, \mathrm{Mpv}, \mathrm{Mc}, \mathrm{Mo}, \mathrm{Mmx}, \mathrm{Mp})$ & 429 & 704 & 3.2 & 31.4 & 85.63 \\
\hline 4 & Chettaba & $6(\mathrm{Mt}, \mathrm{Mpv}, \mathrm{Mmin}, \mathrm{Mo}, \mathrm{Mmx}, \mathrm{Mp})$ & 850 & 558 & 3 & 32.2 & 65.55 \\
\hline 5 & Chaabet ersas & 7 (Mt, Mpv, Mc, Mo, Mmx, Mp, Mc) & 584 & 624 & 3.3 & 32 & 74.58 \\
\hline 6 & Oum Bouaghi & 3 (Mt, Mpv, Mstv) & 883 & 462 & 0.4 & 31.3 & 51.28 \\
\hline 7 & Ouled Hemla & $2(\mathrm{Mt}, \mathrm{Mpv})$ & 795 & 454 & 1.9 & 31.7 & 52.26 \\
\hline 8 & Ain Fakroun & $4(\mathrm{Mt}, \mathrm{Mpv}, \mathrm{Mo}, \mathrm{Mmin})$ & 1010 & 492 & 0.4 & 30.8 & 55.51 \\
\hline 9 & Tipaza & 7 (Mt, Mo, Mmin, Mp, Mlit, Mit ssp helix, Mit ssp tornata) & 196 & 626 & 8.4 & 30.1 & 98.95 \\
\hline 10 & Bourdj bouariridj & $5(\mathrm{Mt}, \mathrm{Mpv}, \mathrm{Mmin}, \mathrm{Mo}, \mathrm{Mrg})$ & 907 & 368 & 1.6 & 33.4 & 39.69 \\
\hline 11 & Mansoura & $2(\mathrm{Mt}, \mathrm{Mrg})$ & 504 & 409 & 3.1 & 32.6 & 47.55 \\
\hline 12 & Lac ain zada & 4 (Mt, Mpv, Mrg, Mmin) & 997 & 495 & 0.2 & 31.1 & 54.95 \\
\hline 13 & Achir & $1(\mathrm{Mt})$ & 984 & 420 & 1.2 & 33.1 & 45.16 \\
\hline 14 & Sidi Belabbes & $3(\mathrm{Mo}, \mathrm{Mp}, \mathrm{Mc})$ & 465 & 450 & 4.8 & 29.7 & 61.99 \\
\hline 15 & Bouira & $5(\mathrm{Mt}, \mathrm{Mpv}, \mathrm{Mp}, \mathrm{Mo}, \mathrm{Mmx})$ & 537 & 506 & 0.2 & 30.9 & 56.53 \\
\hline 16 & Akhdaria & $6(\mathrm{Mt}, \mathrm{Mpv}, \mathrm{Mp}, \mathrm{Mc}, \mathrm{Mint}, \mathrm{Mp})$ & 144 & 711 & 5.9 & 31.9 & 93.80 \\
\hline 17 & Boumerdès & $1(\mathrm{Mp})$ & 20 & 739 & 6.8 & 30.8 & 105.62 \\
\hline 18 & Tizi Ouzou & $1(\mathrm{Mp})$ & 129 & 896 & 6.2 & 32 & 119.12 \\
\hline 19 & El madania & 3 (Mc, Mp, Mlu) & 120 & 707 & 8.1 & 28.5 & 118.87 \\
\hline 20 & Mohamadia & $4(\mathrm{Mt}, \mathrm{Mc}, \mathrm{Mo}, \mathrm{Mp})$ & 3 & 670 & 7.6 & 29.8 & 103.52 \\
\hline 21 & Sidi Fredj & 2 (Mit, Mli) & 1 & 666 & 8.4 & 28.3 & 114.79 \\
\hline 22 & Ben Aknoun & $4(\mathrm{Mt}, \mathrm{Mp}, \mathrm{Mmx}, \mathrm{Mmin})$ & 172 & 762 & 6.9 & 28.4 & 121.57 \\
\hline 23 & Blida & $5(\mathrm{Mt}, \mathrm{Mpv}, \mathrm{Mp}, \mathrm{Mo}, \mathrm{Mc})$ & 70 & 791 & 7 & 30.9 & 113.52 \\
\hline 24 & Mostaganem & 4 (Mp, Mpv, Mmin, Mlit) & 94 & 347 & 8.3 & 27.8 & 61.04 \\
\hline 25 & Khemis Meliana & $4(\mathrm{Mt}, \mathrm{Mpv}, \mathrm{Mc}, \mathrm{Mp})$ & 396 & 593 & 6 & 33.5 & 73.96 \\
\hline 26 & Ain Defla 2 & 9 (Mt, Mc, Mmin, Mp, Mmx, Mpv, Mpv, Mo, Mit ssp corrugata ) & 257 & 593 & 6 & 33.5 & 73.96 \\
\hline 27 & Ain Defla 3 & $3(\mathrm{Mpv}, \mathrm{Mp}, \mathrm{Mc})$ & 382 & 593 & 6 & 33.5 & 73.96 \\
\hline 28 & Relizane & 3 (Mmin, Mp, Mc) & 58 & 348 & 6.8 & 31.1 & 49.12 \\
\hline 29 & Chlef & $5(\mathrm{Mt}, \mathrm{Mpv}, \mathrm{Mp}, \mathrm{Mc}, \mathrm{Mmx})$ & 135 & 405 & 6.6 & 32.6 & 53.43 \\
\hline 30 & Mascara & $4(\mathrm{Mt}, \mathrm{Mp}, \mathrm{Mc}, \mathrm{Mpv})$ & 281 & 368 & 7.5 & 29 & 58.71 \\
\hline 31 & Medea & 7 (Mt, Mo, Mmin, Mmx, Mc, Mpv, Mp) & 385 & 736 & 2.5 & 30.6 & 89.84 \\
\hline 32 & Tissemsilt & $6(\mathrm{Mt}, \mathrm{Mp}, \mathrm{Mpv}, \mathrm{Mc}, \mathrm{Mmin}, \mathrm{Mmx})$ & 575 & 609 & 1.1 & 30.1 & 72.03 \\
\hline 33 & Guelma & $6(\mathrm{Mt}, \mathrm{Mpv}, \mathrm{Mo}, \mathrm{Mc}, \mathrm{Mmx}, \mathrm{Mp})$ & 798 & 564 & 1.9 & 32.1 & 64.06 \\
\hline 34 & Annaba & $4(\mathrm{Mp}, \mathrm{Mpv}, \mathrm{Mo}, \mathrm{Mmx})$ & 132 & 712 & 8.2 & 28.1 & 122.72 \\
\hline 35 & Akbou & 5 (Mc, Mpv, Mh, Mmx, Mint) & 207 & 659 & 6.2 & 31.3 & 90.05 \\
\hline 36 & Tichy & $1(\mathrm{Mp})$ & 2 & 856 & 8.7 & 28.9 & 145.35 \\
\hline 37 & Sétif 1 & 6 (Mt, Mp, Mpv, Mo, Mmin, Marb) & 1022 & 482 & 1 & 31.3 & 54.56 \\
\hline 38 & Sétif 2 & $1(\mathrm{Mt})$ & 1089 & 473 & 0.3 & 31.7 & 51.67 \\
\hline 39 & Eulma & $2(\mathrm{Mmin}, \mathrm{Mlu})$ & 1062 & 473 & 0.3 & 31.7 & 51.67 \\
\hline 40 & Fesdis & $4(\mathrm{Mp}, \mathrm{Mpv}, \mathrm{Mo}, \mathrm{Mt})$ & 946 & 335 & 0.7 & 32.6 & 36.02 \\
\hline 41 & Kissir & $1(\mathrm{Mpv})$ & 166 & 818 & 8.2 & 29.3 & 132.97 \\
\hline 42 & Boughdir & $2(\mathrm{Mpv}, \mathrm{Mo})$ & 132 & 818 & 8.2 & 29.3 & 132.97 \\
\hline 43 & Grand phare & 1 (Mlit) & 9 & 818 & 8.2 & 29.3 & 132.97 \\
\hline 44 & Oran & $4(\mathrm{Mp}, \mathrm{Mpv}, \mathrm{Mt}, \mathrm{Mmin})$ & 87 & 383 & 8.2 & 26.6 & 71.40 \\
\hline 45 & Jeanne d'arc & 1 (Mlit) & 11 & 767 & 7.1 & 28.5 & 122.94 \\
\hline 46 & Oued righa & $2(\mathrm{Mpv}, \mathrm{Mmin})$ & 32 & 767 & 7.1 & 28.5 & 122.94 \\
\hline 47 & Filfila & 1 (Mit) & 159 & 794 & 5.7 & 29.6 & 113.95 \\
\hline
\end{tabular}

* The Mediterranean bioclimatic coefficient of Emberger, $Q 2$, is calculated according to Stewart (1974), $Q 2=3.43 P /(M-m)$, where $P$ is the annual rainfall, $M$ and $m$ are the average of the maximum temperature of the hottest month and the average of the minimum of the coldest month, respectively;

$M t=M$. truncatula, $M p=M$. polymorpha, $M p v=M$. polymorpha var. vulgaris, $M c=M$. ciliaris, $M o=M$. orbicularis, Marb $=M$. arabica, Mmin $=M$. minima, $M m x=M$. murex, $M R g=M$. rigidula, Mit $=$ M. italica, Mlit $=$ M. littoralis, Mint $=$ M. intertexta, Mlu $=$ M. lupulina, Mstv $=$ M. sativa, Mabr $=$ M. arborea

a)

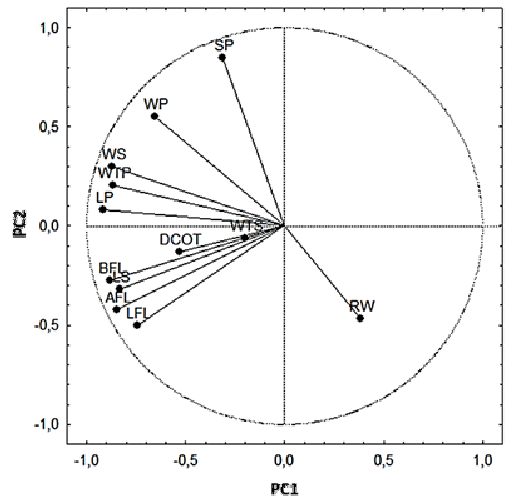

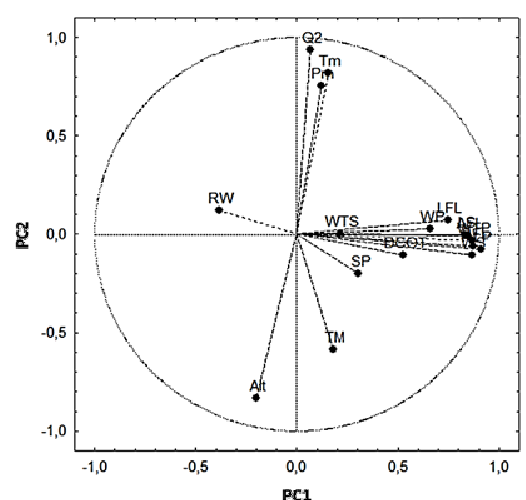

b)

Fig. 2. Principal component analysis of twelve morphological characteristics (a) and their relationship with ecological parameters (b) 
Table 2. Mean, range, standard deviation and coefficient of variation of the analyzed traits for the 13 Medicago species

\begin{tabular}{lccccc}
\hline Traits & Mean & Min. & Max. & s.d. & CV (\%) \\
\hline LP $(\mathrm{mm})$ & 6.42 & 2.39 & 13.28 & 2.91 & 2.37 \\
WP $(\mathrm{mm})$ & 9.20 & 2.01 & 15.53 & 2.95 & 2.43 \\
WTP $(\mathrm{g})$ & 2.84 & 0.06 & 9.45 & 2.24 & 1.41 \\
SP $($ score $)$ & 6.23 & 1 & 28 & 4.48 & 5.61 \\
LS $(\mathrm{mm})$ & 3.34 & 1.81 & 5.37 & 0.80 & 0.18 \\
WS $(\mathrm{mm})$ & 1.96 & 1.08 & 2.98 & 0.46 & 0.06 \\
WTS $(\mathrm{g})$ & 5.53 & 1.03 & 15.64 & 3.74 & 3.91 \\
RW $(\mathrm{g} / \mathrm{g})$ & 2.64 & 0.64 & 21.33 & 2.16 & 1.31 \\
DCOT $(\mathrm{score})$ & 1.62 & 1 & 4 & 0.84 & 0.20 \\
LFL $(\mathrm{mm})$ & 7.63 & 3.39 & 15.10 & 2.24 & 1.40 \\
BFL $(\mathrm{mm})$ & 3.32 & 1.74 & 6.80 & 1.08 & 0.33 \\
AFL $\left.(\mathrm{mm})^{2}\right)$ & 27.19 & 6.17 & 94.55 & 16.99 & 80.79 \\
\hline
\end{tabular}

Min: Minimum, Max: Maximum, s.d.: Standard deviation, CV: Coefficient of Variation, LP: Length of pod, WP: Width of pod, WTP: Weight of 30 pods, SP: Number of seeds per pod, LS: Length of seed, WS: Width of seed, WTS: Weight of thousand seeds, RW: Ratio weight of seeds/Weight of pods, DCOT: Emergence date of cotyledons, LFL: Length of the first leaf, BFL: Breadth of the first leaf, AFL: Area of the first leaf

Table 3. Correlation matrix between the 12 morphological characteristics analyzed $(\mathrm{p}<0.05)$

\begin{tabular}{|c|c|c|c|c|c|c|c|c|c|c|c|c|}
\hline Traits & LP & WP & WTP & SP & LS & WS & WTS & RW & DCOT & LFL & BFL & AFL \\
\hline LP & 1.00 & 0.59 & 0.88 & 0.31 & 0.82 & 0.81 & 0.12 & -0.34 & 0.46 & 0.55 & 0.74 & 0.68 \\
\hline WP & & 1.00 & 0.57 & 0.62 & 0.31 & 0.74 & 0.20 & -0.38 & 0.29 & 0.24 & 0.45 & 0.35 \\
\hline WTP & & & 1.00 & 0.41 & 0.74 & 0.80 & 0.10 & -0.42 & 0.35 & 0.49 & 0.64 & 0.60 \\
\hline SP & & & & 1.00 & -0.09 & 0.54 & -0.03 & -0.38 & 0.09 & -0.12 & 0.10 & -0.02 \\
\hline LS & & & & & 1.00 & 0.66 & 0.19 & -0.24 & 0.37 & 0.73 & 0.71 & 0.73 \\
\hline Ws & & & & & & 1.00 & 0.13 & -0.31 & 0.42 & 0.48 & 0.66 & 0.58 \\
\hline WTS & & & & & & & 1.00 & -0.09 & -0.02 & 0.20 & 0.14 & 0.16 \\
\hline RW & & & & & & & & 1.00 & -0.03 & -0.14 & -0.20 & -0.15 \\
\hline DCOT & & & & & & & & & 1.00 & 0.33 & 0.52 & 0.46 \\
\hline LFL & & & & & & & & & & 1.00 & 0.78 & 0.91 \\
\hline BFL & & & & & & & & & & & 1.00 & 0.94 \\
\hline AFL & & & & & & & & & & & & 1.00 \\
\hline
\end{tabular}

LP: Length of pod, WP: Width of pod, WTP: Weight of 30 pods, SP: Number of seeds per pod, LS: Length of seed, WS: Width of seed, WTS: Weight of thousand seeds, RW: Ratio weight of seeds/Weight of pods, DCOT: Emergence date of cotyledons, LFL: Length of the first leaf, BFL: Breadth of the first leaf, AFL: Area of the first leaf.

\section{Results}

\section{Morphologicalmarkers}

\section{Morphometric characteristics analysis}

Mean, range, s.d. and CV values of the morphological characteristics studied are shown in Table 2. Area of the first leaf (AFL) was found to be the most variable characteristic with CV of $80.79 \%$. Forty-five accessions showed AFL greater than the overall mean. It ranged from $6.17 \mathrm{~mm}^{2}$ to $94.55 \mathrm{~mm}^{2}$ with an average of $27.19 \mathrm{~mm}^{2}$ across all species. Followed by SP with CV value of $5.61 \%$, whence the lowest SP was 1, while the highest was 28. Seed size characteristics (LS and WS), DCOT and BFL displayed the lowest $\mathrm{CV}$ values with $0.18,0.06,0.20$ and 0.33 , respectively.

Fig. 2 a shows the principal component analysis performed on the twelve quantitative traits analyzed. According to Kaiser Standard, we elected the first three axes, which accounted for $76.47 \%$ of the total variation with $50.84 \%$,
$16.68 \%$ and $8.94 \%$ for axis 1,2 and 3, respectively. The component values of each variable were projected in the two first principal components (PC1 and PC2). The characteristics were distributed along PC2 and in the negative values of PC1, except RW, which was negatively correlated with all other characteristics (Table 3). The traits: LP, WP, WTP, LS, WS, LFL, BFL and AFL displayed a relative correlation between them (Table 3 ) and showed the highest contribution to PC1 which differentiates the majority of species. PC2 was influenced essentially by SP characteristic. WTS was misrepresented in the plan 1-2, but contributed highly to the construction of PC3.

\section{Correlation between morphological characteristics and ecological} parameters

In order to ascertain the relationship between morphological traits studied and bioclimate, another PCA (Fig. 2b) was performed taking into account both morphometric characteristics and the five ecological parameters (Alt, Pm, Tm, TM and Q2). The first four axes explained $74.22 \%$ of the total variation $(36.40 \%, 19.08 \%, 11.74 \%$ and $6.99 \%$, respectively). All the characteristics formed a group strongly contributed to the formation of PC1, excluding SP and W'TS that showed high loadings in relation to $\mathrm{PC} 3$ and $\mathrm{PC} 4$, respectively, whereas climatic parameters displayed another group along $\mathrm{PC} 2$. This distribution of variables indicates a very low correlation between morphological characteristics and bioclimate. Whence, the closest relationship was found between TM and WTS with $r=$ 0.26 and the strongest negative correlation was shown between Alt and WP with $r=-0.19$ when $\mathrm{p}<0.05$ (data not shown).

\section{Cluster analysis based on morphological characteristics}

Euclidean distances values based on the twelve quantitative traits were represented in a UPGMA phenogram (Fig. 3). The topology of the phenogram subdivided the species at a distance level $\mathrm{d}=33.09$ into two major clusters. Cluster I included six species with highest values of morphological characteristics $(M$. ciliaris, $M$. rigidula, $M$. intertexta, $M$. murex, $M$. italica and $M$. arborea) and was especially characterized by the highest WTS. The second cluster is subdivided into three main groups at a high distance level $\mathrm{d}=24.17$. All species presented intermediate

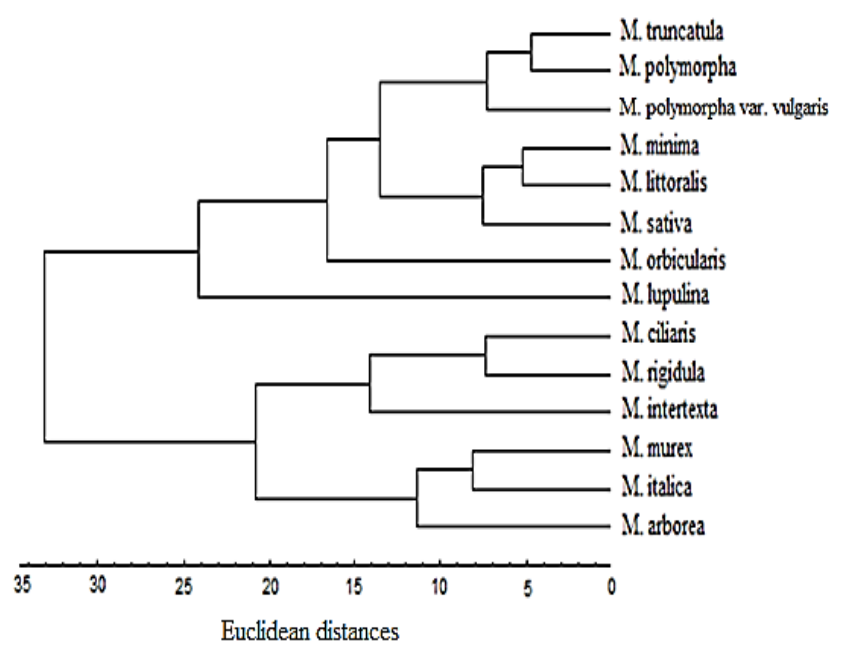

Fig. 3. UPGMA dendrogram based on morphological characteristics of 13 species of the genus Medicago L. 


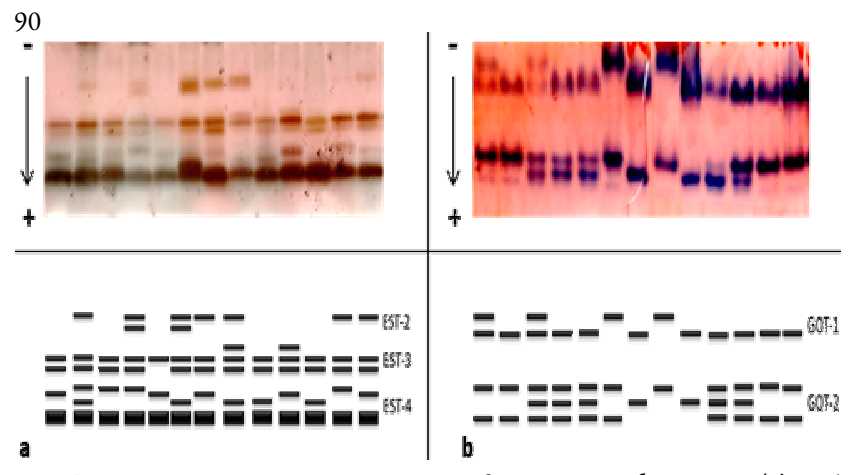

Fig. 4. Zymograms in some accessions of $M$. truncatula esterase (a) and M. polymorpha glutamate oxaloacetate transaminase (b)

dimensions of morphological characteristics (M. truncatula, $M$. polymorpha, $M$. polymorpha var. vulgaris, $M$. minima, $M$. littoralis and M. sativa) form the group I at distance value $\mathrm{d}=$ 13.51. The second group (II) linked to the first one at the level d = 16.69; was composed of one species (M. orbicularis) which was different from the other species by the highest SP. The third group (III) was formed by the most distant species (M. lupulina); this one was characterized by the lowest morphological traits. According to the morphometric markers, the smallest genetic distance was observed between $M$. truncatula and $M$. polymorpha (4.8) followed by M. minima and M. littoralis (5.2).

\section{Isozyme markers}

The revealed zymograms displayed a number of variable bands according to the system and analysed species. Examples of zymograms for the two enzymatic systems studied (EST and GOT) and their diagrammatical representations are shown in Fig. 4. A total of six isozyme loci with 32 bands were detected and 92 isoenzyme phenotypes were recorded for the two enzymes analyzed. Frequencies of isoenzyme phenotypes are given in Table 4 .

\section{Phenotypefrequencies}

Ten bands were scored based on the GOT enzyme system, attributed to 2 loci with 9 and 12 types of zymograms for Got-1 and Got-2, respectively. The number of bands varies from 1 to 3 at the 2 loci (Fig. 4b). The Got-1 isozyme type A, which is characterized by only one allozyme (band 4) was the most common and present in all the fourteen species analyzed with 0.77 frequency (Table 4). All other isozyme types of this locus were considered to be rare. At the Got-2 locus, the most frequent isozyme type was Got-2A (encoding the allozyme 9) with 0.36 frequency. This one was absent in five species but present in all accessions of $M$. truncatula, $M$. littoralis and $M$. rigidula (1.00), followed by isozyme types $\mathrm{D}$ and $\mathrm{F}$ with frequencies 0.17 and 0.14 , respectively. The lowest frequency $(0.01)$ was observed for the isozyme types $\mathrm{C}, \mathrm{I}, \mathrm{K}$ and $\mathrm{L}$, which were only present in one accession of M.polymorpha, variaties M. polymorpha var. vulgaris and $M$. ciliaris, respectively.

Four zones of activity considered as product of four EST loci were observed among all 169 accessions. In total twenty-two EST bands attributed to 6, 20, 23 and 22 isozyme types for Est-1, Est-2, Est-3 and Est-4, respectively were recorded. All species represented by several accessions showed intra-specific variation for esterase system. The Est-l locus was only observed in the two M. polymorpha varieties and M. intertexta. A and B phenotypes represented the two varieties: M.polymorpha and M.polymorpha var. vulgaris with frequencies 0.09 and 0.11 , respectively. $M$. intertexta was characterized by the presence of the isozyme type C, which was also present in M. polymorpha var. polymorpha at a low frequency. The Est-1 phenotype $\mathrm{F}$ was very rare; hence, it was present in uniquely one accession of $M$. polymorpha. The loci Est-2, Est-3 and Est-4 were present across the collection with a high phenotypes number and variability. The isozyme types: $\mathrm{C}$ of Est-2, C of Est-3 and $\mathrm{F}$ of Est-4 were the most frequent with $0.15,0.21$ and 0.27 frequencies, respectively. The Est-4 phenotype (F) was characteristic of $M$. polymorpha and $M$. polymorpha var. vulgaris and it was present with high frequencies: 0.68 and 0.96 in the two varieties, respectively. A considerable number of rare and species-specific phenotypes with relatively low frequencies were recorded in these three loci (Table 4); as an example, phenotypes P, E and $\mathrm{N}$ of Est-2, Est-3 and Est-4 respectively, were only observed in two species, $M$. ciliaris and $M$. intertexta, hence, the phenotypes $\mathrm{E}$ and $\mathrm{N}$ exhibited two bands (11 and 22, respectively), which were species-specific to these two species.

\section{Phenotypicpolymorphism}

The amounts of phenotypic polymorphism for each isozyme locus in each species $(\mathrm{Pj})$ are reported in Table 5 . The two GOT enzyme system loci (Got-1 and Got-2) were monomorphic in some species and polymorphic in others, presenting average phenotypic polymorphism values $(\hat{\mathbf{P}})$ of 0.18 and 0.21 respectively. However, these loci were highly polymorphic within the two varieties M.polymorpha and M. polymorpha var. vulgaris followed by $M$. minima with lower values of phenotypic polymorphism $(\mathrm{Pj})$, but considered monomorphic in the four species $M$. truncatula, $M$. orbicularis, $M$. littoralis and $M$. intertexta with values of phenotypic polymorphism $(\mathrm{Pj})$ ranging from 0.00 to 0.10 . The Est-1 isozyme had the lowest polymorphism value because it was present only in the two $M$. polymorpha varieties, but with a high level of genetic variation in each. The highest polymorphism indices $(\hat{\mathbf{P}})$ were recorded in the three EST loci: Est-2, Est-3 and Est-4 with values of 0.39, 0.44 and 0.38 respectively, since all species were polymorphic for these EST loci with relatively high levels of variation, with $\mathrm{Pj}$ values ranging from 0.07 to 0.75 (Table 5). Based on the polymorphism values for each locus, differences between species could be observed. Generally, all the species displayed more or less important genetic diversity. The two varieties of $M$. polymorpha species showed the highest intraspecific variation across all the loci with $\widehat{\mathbf{P}}$ of 0.57 for each, followed by $M$. italica and $M$. ciliaris with $\widehat{\mathbf{P}}$ of 0.44 and 0.41 , respectively. The three species $M$. sativa, $M$. arborea and $M$. arabica disclosed a null phenotypic polymorphism amount $(\widehat{\mathbf{P}}=0.00)$ because they were represented by only one accession in the study.

\section{Cluster analysis based on isozyme variability}

Interesting information in interspecific variability is obtained with cluster analysis. The UPGMA dendrogram based on distances matrix of the species wise pooled zymogram (Fig. 5) agrees with taxonomic criteria and showed two major clusters. The first one was composed of two species belonging to the subsection Leptospireae of the section Spirocarpos, namely $M$. polymorpha and $M$. arabica. The second cluster was the largest and embodied the remaining species belonging to five sections namely Spirocarpos, Orbiculares, Medicago, Lupularia and 
Table 4. Isozyme types frequencies at six loci in fifteen species of the genus Medicago

\begin{tabular}{|c|c|c|c|c|c|c|c|c|c|c|c|c|c|c|c|c|c|}
\hline \multirow{3}{*}{ Loci } & \multirow{3}{*}{ Phenotypes } & \multirow{3}{*}{ Total } & \multicolumn{15}{|c|}{ Species } \\
\hline & & & $M t$ & $M p$ & $M p \cdot v$ & $M c$ & Mo & Mmin & $M m x$ & Mit & Mlit & $M R g$ & $M l u$ & Mint & Mstv & Mabr & Marb \\
\hline & & & 29 & 28 & 28 & 19 & 18 & 15 & 12 & 5 & 5 & 3 & 2 & 2 & 1 & 1 & 1 \\
\hline \multirow[t]{9}{*}{ Got-1 } & A: 4 & 0.77 & 0.97 & 0.68 & 0.50 & 1.00 & 1.00 & 0.87 & 0.08 & 1.00 & 1.00 & 0.67 & 0.50 & 1.00 & 1.00 & 1.00 & 1.00 \\
\hline & B:5 & 0.02 & 0.03 & - & - & - & - & 0.13 & - & - & - & - & - & - & - & - & - \\
\hline & C: $3+4$ & 0.08 & - & 0.18 & 0.25 & - & - & - & 0.17 & - & - & - & - & - & - & - & - \\
\hline & D: $1+4$ & 0.01 & - & 0.04 & - & - & - & - & - & - & - & - & - & - & - & - & - \\
\hline & E: $3+4+5$ & 0.01 & - & 0.04 & - & - & - & - & - & - & - & - & - & - & - & - & - \\
\hline & $\mathrm{F}: 3$ & 0.05 & - & 0.07 & 0.25 & - & - & - & - & - & - & - & - & - & - & - & - \\
\hline & $\mathrm{G}: 2+4$ & 0.05 & - & - & - & - & - & - & 0.75 & - & - & - & - & - & - & - & - \\
\hline & $\mathrm{H}: 4+6$ & 0.01 & - & - & - & - & - & - & - & - & - & 0.33 & - & - & - & - & - \\
\hline & $\mathrm{I}: 2+5$ & 0.01 & - & - & - & - & - & - & - & - & - & - & 0.50 & - & - & - & - \\
\hline \multirow[t]{12}{*}{ Got-2 } & A:9 & 0.36 & 1.00 & 0.07 & 0.07 & - & - & 0.93 & - & 0.60 & 1.00 & 1.00 & - & - & 1.00 & 1.00 & 1.00 \\
\hline & B: $7+8$ & 0.03 & - & 0.11 & - & 0.11 & - & - & - & - & - & - & - & - & - & - & - \\
\hline & C: $7+9$ & 0.01 & - & 0.04 & - & - & - & - & - & - & - & - & - & - & - & - & - \\
\hline & D: $8+9$ & 0.17 & - & 0.14 & 0.18 & 0.21 & - & - & 1.00 & 0.20 & - & - & 1.00 & - & - & - & - \\
\hline & E: $7+8+9$ & 0.02 & - & 0.11 & 0.00 & 0.05 & - & - & - & - & - & - & - & - & - & - & - \\
\hline & F: $8+10$ & 0.14 & - & 0.25 & 0.39 & 0.16 & 0.06 & - & - & - & - & - & - & 1.00 & - & - & - \\
\hline & G:8 & 0.08 & - & 0.11 & 0.14 & 0.37 & - & - & - & - & - & - & - & - & - & - & - \\
\hline & $\mathrm{H}: 8+9+10$ & 0.06 & - & 0.18 & 0.18 & - & - & - & - & - & - & - & - & - & - & - & - \\
\hline & I: $9+10$ & 0.01 & - & - & 0.04 & - & - & - & - & - & - & - & - & - & - & - & - \\
\hline & $\mathrm{J}: 10$ & 0.11 & - & - & - & - & 0.94 & 0.07 & - & - & - & - & - & - & - & - & - \\
\hline & $\mathrm{K}: 7+8+10$ & 0.01 & - & - & - & 0.05 & - & - & - & - & - & - & - & - & - & - & - \\
\hline & L:7 & 0.01 & - & - & - & 0.05 & - & - & - & 0.20 & - & - & - & - & - & - & - \\
\hline
\end{tabular}

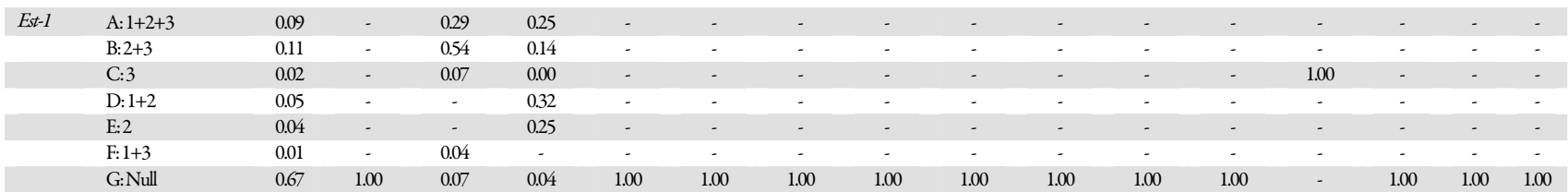

\begin{tabular}{|c|c|c|c|c|c|c|c|c|c|c|c|c|c|c|c|c|c|}
\hline Est-2 & A: $5+6$ & 0.02 & 0.10 & - & - & - & - & - & - & - & - & - & - & - & - & - & - \\
\hline & B: 5 & 0.13 & 0.45 & - & - & 0.05 & - & 0.47 & - & - & 0.20 & - & - & - & - & - & - \\
\hline & C: 6 & 0.15 & 0.07 & 0.07 & 0.14 & - & 0.72 & - & - & - & 0.80 & - & - & - & - & - & - \\
\hline & $\mathrm{D}: 5+6+7$ & 0.09 & - & 0.57 & - & - & - & - & - & - & - & - & - & - & - & - & - \\
\hline & $\mathrm{E}: 6+7$ & 0.09 & - & 0.25 & 0.32 & - & - & - & - & - & - & - & - & - & - & - & - \\
\hline & F:7 & 0.03 & - & 0.07 & 0.04 & - & - & - & 0.08 & 0.20 & - & - & - & - & - & - & - \\
\hline & G: $4+6+7$ & 0.06 & - & - & 0.36 & - & - & - & - & - & - & - & - & - & - & - & - \\
\hline & $\mathrm{H}: 4+6$ & 0.01 & - & - & 0.07 & - & - & - & - & - & - & - & - & - & - & - & - \\
\hline & I: 8 & 0.09 & - & - & - & 0.79 & - & - & - & - & - & - & - & - & - & - & - \\
\hline & $\mathrm{J}: 5+9$ & 0.05 & - & - & - & - & - & 0.53 & - & - & - & - & - & 0.50 & - & - & - \\
\hline & K:9 & 0.07 & - & - & - & - & 0.11 & - & 0.58 & - & - & 0.33 & 1.00 & - & - & - & - \\
\hline & L: 4 & 0.03 & - & - & 0.04 & - & - & - & - & 0.40 & - & - & - & - & 1.00 & 1.00 & - \\
\hline & $\mathrm{M}: 8+9$ & 0.02 & - & - & - & - & - & - & 0.25 & - & - & - & - & - & - & - & - \\
\hline & $\mathrm{N}: 7+9$ & 0.02 & - & - & - & 0.05 & - & - & 0.08 & 0.20 & - & - & - & - & - & - & - \\
\hline & $0: 6+9$ & 0.02 & - & - & - & - & 0.17 & - & - & - & - & - & - & - & - & - & - \\
\hline & P: $5+8$ & 0.01 & - & - & - & 0.05 & - & - & - & - & - & - & - & 0.50 & - & - & - \\
\hline & Q:5+7 & 0.01 & - & 0.04 & - & - & - & - & - & - & - & - & - & - & - & - & - \\
\hline & $\mathrm{R}: 4+7$ & 0.01 & - & - & 0.04 & - & - & - & - & - & - & - & - & - & - & - & - \\
\hline & $S: 5+8+9$ & 0.01 & - & - & - & 0.05 & - & - & - & - & - & - & - & - & - & - & - \\
\hline & $\mathrm{T}: 4+5+6$ & 0.01 & - & - & - & - & - & - & - & - & - & - & - & - & - & - & 1.00 \\
\hline
\end{tabular}

\begin{tabular}{|c|c|c|c|c|c|c|c|c|c|c|c|c|c|c|c|c|c|}
\hline & & & & & & & & & & & & & & & & & \\
\hline & U:Null & 0.08 & 0.38 & - & - & - & - & - & - & 0.20 & - & 0.67 & - & - & - & - & - \\
\hline \multirow[t]{24}{*}{ Est-3 } & A: $12+14$ & 0.08 & 0.45 & - & - & - & - & - & - & - & 0.20 & - & - & - & - & - & - \\
\hline & B: $10+12+14$ & 0.09 & 0.52 & - & - & - & - & - & - & - & - & - & - & - & - & - & - \\
\hline & C: 12 & 0.21 & 0.03 & 0.68 & 0.43 & - & - & - & - & - & 0.20 & 0.67 & - & - & - & - & - \\
\hline & D: $11+14$ & 0.07 & - & - & - & 0.58 & - & - & - & - & - & - & - & - & - & - & - \\
\hline & E: $11+13$ & 0.04 & - & - & - & 0.32 & - & - & - & - & - & - & - & 0.50 & - & - & - \\
\hline & $F: 10+15$ & 0.05 & - & - & - & - & 0.44 & - & - & - & - & - & - & - & - & - & - \\
\hline & G: $10+14+15$ & 0.04 & - & - & - & - & 0.33 & - & - & - & - & - & - & - & - & - & - \\
\hline & $\mathrm{H}: 15$ & 0.04 & - & - & - & - & 0.17 & 0.27 & - & - & - & - & - & - & - & - & - \\
\hline & I: $13+15$ & 0.04 & - & - & - & - & - & 0.47 & - & - & - & - & - & - & - & - & - \\
\hline & $\mathrm{J}: 14$ & 0.05 & - & - & - & - & - & - & 0.58 & - & - & - & 0.50 & - & 1.00 & - & - \\
\hline & $\mathrm{K}: 10+14$ & 0.02 & - & - & - & - & - & - & 0.25 & - & - & - & - & - & - & - & - \\
\hline & $\mathrm{L}: 10+12$ & 0.02 & - & - & - & - & - & - & - & 0.20 & 0.60 & - & - & - & - & - & - \\
\hline & M: 13 & 0.01 & - & - & - & - & - & - & - & - & - & 0.33 & - & 0.50 & - & - & - \\
\hline & $N: 12+16$ & 0.01 & - & - & - & - & - & - & - & 0.40 & - & - & - & - & - & - & - \\
\hline & $\mathrm{O}: 12+13$ & 0.01 & - & - & - & - & - & - & - & - & - & - & - & - & - & 1.00 & - \\
\hline & P: $10+13$ & 0.01 & - & - & - & - & - & - & - & 0.20 & - & - & - & - & - & - & - \\
\hline & Q: $10+12+13+16$ & 0.01 & - & - & - & - & - & - & - & 0.20 & - & - & - & - & - & - & - \\
\hline & $R: 13+15+16$ & 0.01 & - & - & - & - & - & 0.13 & - & - & - & - & - & - & - & - & - \\
\hline & S: $10+13+15+16$ & 0.01 & - & - & - & - & - & 0.07 & - & - & - & - & - & - & - & - & - \\
\hline & $\mathrm{T}: 10+13+15$ & 0.01 & - & - & - & - & - & 0.07 & - & - & - & - & - & - & - & - & - \\
\hline & $\mathrm{U}: 14+15$ & 0.01 & - & - & - & - & 0.06 & - & - & - & - & - & - & - & - & - & - \\
\hline & $V: 11+14+16$ & 0.01 & - & - & - & 0.05 & - & - & - & - & - & - & - & - & - & - & - \\
\hline & $\mathrm{W}: 11+13+14$ & 0.01 & - & - & - & 0.05 & - & - & - & - & - & - & - & - & - & - & - \\
\hline & X:Null & 0.17 & - & 0.32 & 0.57 & - & - & - & 0.17 & - & - & - & 0.50 & - & - & - & 1.00 \\
\hline
\end{tabular}




\begin{tabular}{|c|c|c|c|c|c|c|c|c|c|c|c|c|c|c|c|c|c|}
\hline \multirow[t]{22}{*}{ Est-4 } & A: $18+20$ & 0.10 & 0.48 & - & - & - & 0.06 & - & - & 0.20 & 0.20 & - & - & - & - & - & - \\
\hline & B: $17+20$ & 0.06 & 0.14 & - & - & - & - & - & - & 0.40 & 0.80 & - & - & - & - & - & - \\
\hline & C: $19+20$ & 0.08 & 0.28 & - & - & - & - & - & 0.42 & - & - & - & - & - & - & - & - \\
\hline & D: $17+19+20$ & 0.07 & 0.03 & 0.32 & - & - & - & - & 0.08 & - & - & - & - & - & - & - & - \\
\hline & E:20 & 0.02 & 0.07 & - & - & - & - & - & - & 0.40 & - & - & - & - & - & - & - \\
\hline & F: $17+19$ & 0.27 & - & 0.68 & 0.96 & - & - & - & - & - & - & - & - & - & - & - & - \\
\hline & G: $18+19$ & 0.07 & - & - & - & - & 0.06 & 0.73 & - & - & - & - & - & - & - & - & - \\
\hline & H: 19 & 0.04 & - & - & 0.04 & - & - & 0.27 & - & - & - & 0.33 & - & - & - & - & 1.00 \\
\hline & I: $18+21+22$ & 0.02 & - & - & - & 0.21 & - & - & - & - & - & - & - & - & - & - & - \\
\hline & $\mathrm{J}: 22$ & 0.01 & - & - & - & 0.05 & - & - & - & - & - & - & - & - & - & - & - \\
\hline & K: $17+18+20$ & 0.01 & - & - & - & - & - & - & - & - & - & - & - & - & 1.00 & - & - \\
\hline & L: $17+18+22$ & 0.01 & - & - & - & 0.05 & - & - & - & - & - & - & - & - & - & - & - \\
\hline & M: $17+18+21$ & 0.02 & - & - & - & 0.11 & 0.06 & - & - & - & - & - & - & - & - & - & - \\
\hline & $\mathrm{N}: 18+19+21$ & 0.01 & - & - & - & 0.05 & - & - & - & - & - & - & - & 0.50 & - & - & - \\
\hline & O: $19+20+21$ & 0.03 & - & - & - & - & - & - & 0.42 & - & - & - & - & - & - & - & - \\
\hline & P: $18+21$ & 0.15 & - & - & - & 0.42 & 0.83 & - & - & - & - & 0.67 & - & - & - & - & - \\
\hline & Q: $17+18+19+21$ & 0.01 & - & - & - & 0.05 & - & - & - & - & - & - & - & - & - & - & - \\
\hline & R: $18+20+21$ & 0.01 & - & - & - & 0.05 & - & - & - & - & - & - & - & - & - & 1.00 & - \\
\hline & S: $17+18+19$ & 0.01 & - & - & - & - & - & - & 0.08 & - & - & - & - & - & - & - & - \\
\hline & $\mathrm{T}: 17+21$ & 0.01 & - & - & - & - & - & - & - & - & - & - & 0.50 & - & - & - & - \\
\hline & U: $17+20+21$ & 0.01 & - & - & - & - & - & - & - & - & - & - & 0.50 & - & - & - & - \\
\hline & $\mathrm{V}: 18+19+21+22$ & 0.01 & - & - & - & - & - & - & - & - & - & - & - & 0.50 & - & - & - \\
\hline
\end{tabular}

Table 5. Phenotypic polymorphism for each of the six loci in each of the studied species

\begin{tabular}{lccccccc}
\hline \multirow{2}{*}{ Species } & \multicolumn{7}{c}{ Isozymes } \\
\cline { 2 - 8 } & Got-1 & Got-2 & Est-1 & Est-2 & Est-3 & Est-4 & Mean \\
\hline M. truncatula & 0.07 & 0.00 & 0.00 & 0.64 & 0.53 & 0.66 & 0.32 \\
M. polymorpha & 0.50 & 0.84 & 0.62 & 0.59 & 0.44 & 0.44 & 0.57 \\
\hline M. polymorpha var. vulgaris & 0.62 & 0.75 & 0.75 & 0.74 & 0.49 & 0.07 & 0.57 \\
M. ciliaris & 0.00 & 0.77 & 0.00 & 0.36 & 0.56 & 0.75 & 0.41 \\
\hline M. orbicularis & 0.00 & 0.10 & 0.00 & 0.43 & 0.66 & 0.29 & 0.25 \\
M. minima & 0.23 & 0.12 & 0.00 & 0.49 & 0.68 & 0.39 & 0.32 \\
\hline M. murex & 0.40 & 0.00 & 0.00 & 0.58 & 0.57 & 0.64 & 0.37 \\
M. italica & 0.00 & 0.56 & 0.00 & 0.72 & 0.72 & 0.64 & 0.44 \\
\hline M. littoralis & 0.00 & 0.00 & 0.00 & 0.32 & 0.56 & 0.32 & 0.20 \\
M. rigidula & 0.44 & 0.00 & 0.00 & 0.44 & 0.44 & 0.44 & 0.30 \\
\hline M. lupulina & 0.50 & 0.00 & 0.00 & 0.00 & 0.50 & 0.50 & 0.25 \\
M. intertexta & 0.00 & 0.00 & 0.00 & 0.50 & 0.50 & 0.50 & 0.25 \\
\hline M. sativa & 0.00 & 0.00 & 0.00 & 0.00 & 0.00 & 0.00 & 0.00 \\
M. arborea & 0.00 & 0.00 & 0.00 & 0.00 & 0.00 & 0.00 & 0.00 \\
\hline M. arabica & 0.00 & 0.00 & 0.00 & 0.00 & 0.00 & 0.00 & 0.00 \\
Mean & 0.18 & 0.21 & 0.09 & 0.39 & 0.44 & 0.38 & 0.28 \\
\hline
\end{tabular}

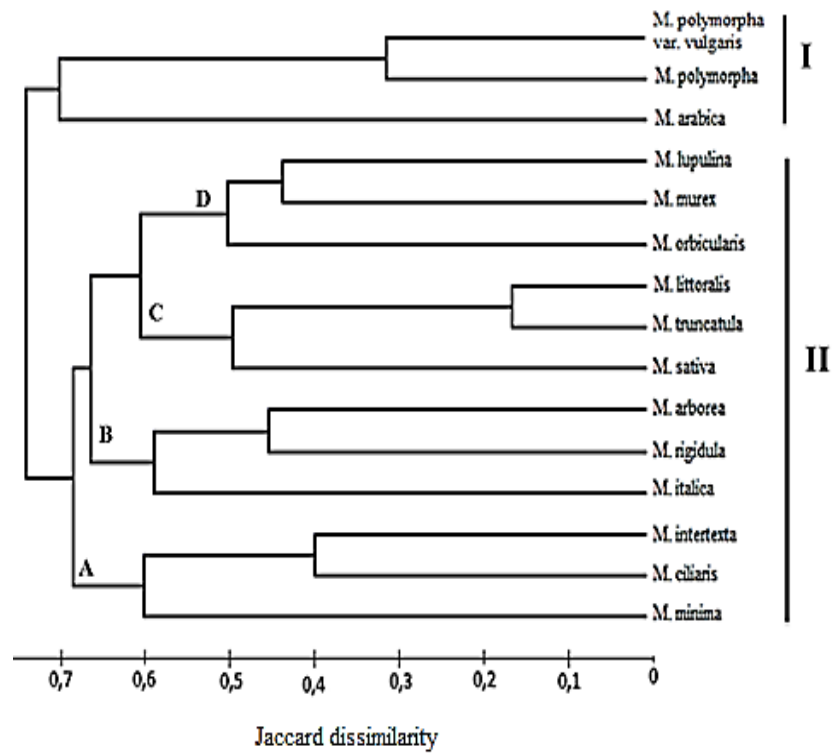

Fig. 5. UPGMA dendrogram based on isozyme data of 14 species of the genus Medicago L.

Dendrotelis. This cluster is subdivided at high close distances into four sub-clusters (A, B, C and D) each having three species only (Fig. 5). M. intertexta, $M$. ciliaris and $M$. minima formed the sub-cluster $A$ at a distance level of 0.69 . The sub-cluster B comprised of $M$. arborea, $M$. rigidula and $M$. italica joined with the sub-clusters $\mathrm{C}$ (M. littoralis, $M$. truncatula and $M$. sativa) and $\mathrm{D}$ (M. lupulina, $M$. murex and $M$. orbicularis) at 0.66 level of distance. These last sub-clusters (C and D) were distinguished from one another at distance of 0.61. M. truncatula and $M$. littoralis both belonging to subsection Pachyspireae of the section Spirocarpos showed the highest similarity between them, with Jaccard's index of 0.17 , followed by the two varieties of $M$. polymorpha at dissimilarity value of 0.32 , then $M$. ciliaris and $M$. intertexta both belonging to subsection Intertextae of the section Spirocarpos, with Jaccard's index of 0.4. Despite the fact that are belonging to different sections, the two species M. lupulina and $M$. murex as well as $M$. arborea and $M$. rigidula showed a significant similarity between them.

Finally, Mantel Z-statistical analysis based on Pearson correlation showed no significant correlation $(r=0.092, p=$ $0.395)$ between morphological and isozyme distance matrices.

\section{Discussions}

In this screening of genetic divergence in natural populations of the genus Medicago L., morphological and isozyme markers were compared for fourteen species represented by 169 accessions collected in wide range of climatic stages in Northern Algeria. The importance of morphological variation among the examined species is demonstrated by the PCA analysis on twelve quantitative traits and the topology of the dendrogram based on Euclidean distance that showed the discrimination of the species under study.

The majority of morphological characteristics analyzed in this study were important in the differentiation of the species. Pod size (LP and WP), WTP, seed size (LS and WS) and seedling traits (DCOT, LFL, BFL and AFL) participated strongly to the discrimination of all the species into two mean groups: a group included species with high measured values of morphological characteristics (M. ciliaris, $M$. intertexta, $M$. rigidula, $M$. murex, $M$. italica and $M$. arborea) and a second group embodied the remaining species characterized by intermediate to low measured values of morphological characteristics. 
The importance of these traits is evidenced by its high loadings in the first principal component. Seedling traits: LFL, BFL and AFL had large genetic correlations among them (Table 2); this finding was also observed by Bonnin et al. (1996) when analyzing Medicago truncatula population structure by quantitative genetic markers. The characteristic SP which contributed strongly to PC2 differentiates the two species (M. orbicularis and M. lupulina) from one another and from the other species. Hence, it is known that $M$. orbicularis is characterized by a high number of seeds per pod, while M. lupulina is characterized by only one seed per pod (Lesins and Lesins, 1979). Another characteristic with great contribution to PC3 was WTS, it allowed the ingathering of species with high seed size, e.g. $M$. ciliaris, $M$. intertexta, $M$. murex and M. rigidula. Lesins and Lesins (1979) noted the relationship between these traits and reported that the weight of 1,000 seeds give a priori a fair idea about the size of the seeds.

Our results showed that there were significant morphological variations within and among species in terms of pod, seed and seedling traits. Moreover, all taxonomists used fruit traits (pod and seed) as an important key for distinguishing species of the genus Medicago L. (Heyn, 1963; Lesins and Lesins, 1979; Quezel and Santa, 1962; Small and Jomphe, 1989). This high morphological variation is consistent with findings of many genetic diversity studies on Medicago L. germplasm collections (Al-Faifi et al., 2013; Bonnin et al., 1996; Bullita et al., 1994; Cherifi et al., 1993; El Hansali et al., 2007; Radwan et al., 1980; Tucak et al., 2008; Zivković et al., 2012).

The even large differentiation among and within these Algerian wild pool for quantitative characteristics is probably due to the vast geographic area that is represented, and thus the large heterogeneity among habitats encountered. Nonetheless, this hypothesis is rejected by our finding about the relationship between environment and phenotypic features, whence no significant correlation was appreciated. Various studies on the genus Medicago L. revealed positive correlation between morphological traits and climatic factors (Abdelguerfi and Laouar, 1999; Al-Faifi et al., 2013; Zivković et al., 2012). Prosperi et al. (2006) when evaluating morphologic and agronomic diversity of wild genetic resources of Medicago sativa $\mathrm{L}$. in Spain found low significant correlations between the two sets of variables (morphology and bioclimate) and noticed that the environmental characteristics that influence more the phenotypic traits of the natural populations studied were the altitude, summer rainfall and latitude.

Because morphological traits only represent a part of the genetic diversity, and because the organization of this diversity is highly subject to natural selection and environmental factors, knowledge of the evolution and dynamics of populations requires analysis of more neutral markers such as isozymes that should help to specify the genetic structure of populations. The two enzymatic systems (EST and GOT) revealed high genetic diversity within and among the species studied, hence, six loci with 32 bands and 92 phenotypes were detected.

This result is in agreement with findings of many enzymatic variation studies on Medicago populations (Bullitta et al., 1994; Chandra et al., 2011; Cherifi, 1996;
Haddioui et al., 2012; Jenczewski et al., 1999a, 1999b). This important enzymatic variability could be the result of the fact that the majority of these species are annual reputed to be autogamous (Hamrick and Godt, 1990).

EST are a complex and heterogeneous enzyme group with multiple substrate specificity (Scandalios, 1969) and one of the enzymatic systems with a high polymorphism in plants (Weeden and Wendel, 1990). In the current study, the estimate showed highest variability for EST isozymes, recording four loci with 71 types and all 22 bands contributed this difference. A lower genetic diversity was detected based on GOT enzymatic system, thus, two loci and 10 bands attributed to 21 phenotypes were scored across the collection. However, in addition to EST enzyme, high intra-specific variation was observed in the two varieties of $M$. polymorpha for GOT enzyme too. Similar results were found by Bullitta et al. (1994), Hannachi (1998), Paredes et al. (2002), suggesting that the high levels of autogamy in this species result in a strong pattern of among population genetic differentiation.

The topology of the dendrogram based on Jaccard's index generated from the isozyme binary data matrix was logical and the mean Jaccard's indices of the fourteen species ranged from 0.18 to 0.59 with an average of 0.37 . This wide range of similarity indices reflects a high degree of polymorphism at isozyme level. This type of clustering was used also by Chandra et al. (2011) who estimated a high level of similarity among accessions and species of the genus Medicago L. The most similar species were $M$. truncatula and $M$. littoralis. This is in agreement with taxonomic criteria; hence, this two species belong to the same subsection (Pachyspireae). Valizadeh et al. (1996) when estimated genetic distances among nine species of Medicago based on RFLP markers, showed that $M$. truncatula and $M$. littoralis were the most similar, that makes isozyme markers as important as molecular ones. Strong similarity was observed also between the two M. polymorpha varieties (polymorpha and vulgaris) which were characterized by the presence of band 4 and band 5, respectively, based on EST enzyme system. M. ciliaris and $M$. intertexta showed also a high similarity between them, since belonging to the subsection Intertextae (Small and Jomphe, 1989). The close isozyme relationship among these two species was already elucidated (Cherifi, 1996).

The Mantel test $(r=0.092, p=0.395)$ indicated no significant correlation between the matrix based on morphological characteristics and that derived from the enzymatic analysis. Therefore, clustering of accessions based on morphological characteristics was inconsistent with that derived from the isozyme markers analysis. The result suggests that the two marker systems give different estimates of genetic relations among populations. A large number of studies have been published that detail the comparative divergence of phenotypic and allozymic characteristics (Bonnin et al., 1996; Jenczewski et al., 1999a; Long and Singh, 1995; Podolsky and Holtsford, 1995; Spitze, 1993; Yang et al., 1996). Most of these have reported stronger differences with analyses of quantitative traits data than with electrophoretic ones and have suggested that natural selection acting upon the quantitative traits is responsible for the different patterns of differentiation revealed by neutral and quantitative traits. 
94

\section{Conclusions}

In conclusion, the present study gives an insight into the rich variability and relationships present within and between Algerian Medicago species at morphological and enzymatic levels. This may allow greater understanding of the evolution of morphological and biochemical characteristics in this genus. In addition, the studied accessions can prove to be a good genetic source for further improvement programs. Moreover, certain species were having specific zymograms, hence, could serve as markers for species identification. In order to define more the genetic diversity of this Medicago collection, it is necessary to include protein and molecular analysis to have a complete understanding of the starting material for breeding purposes.

\section{References}

Abdelguerfi A, Laouar M (1999). Autoécologie et variabilité de quelques légumineuses d'intéret fourrager et/ou pastoral: possibilités de valorisation en région Méditerranéenne. [Autecology and variability of some legumes of fodder and/or pastoral interest: valorization possibilities in Mediterranean region]. Pastagens e Forragens 20:81-112.

Al-Faifi SA, Migdadi HM, Al-Doss A, Ammar MH, El-Harty EH, Khan MA, Muhammad JM, Alghamdi SS (2013). Morphological and molecular genetic variability analyses of Saudi lucerne (Medicago sativa L.) landraces. Crop \& Pasture Science 64:137-146.

Al-Mouemar A, Gasquez J (1983). Environmental conditions and isozyme polymorphism in Chenopodium album L. Weed Research 23:141-149.

Bailly X, Olivieri I, Brunel B, Cleyet-Marel JC, Bena G (2007). Horizontal gene transfer and homologous recombination drive the evolution of the nitrogen-fixing symbionts of Medicago species. Journal of Bacteriology 189:5223-5236.

Bell C, Dixon R, Farmer A (2001). The Medicago genome initiative: a model legume database. Nucleic Acids Research 29(1):114-117.

Bena G, Prosperi JM, Lejeune B, Olivieri I (1998). Evolution of annual species of the genus Medicago: A molecular phylogenetic approach. Molecular Phylogenetics Evolution 9:552-559.

Bendiab K, Baaziz M, Brakez Z, Sedra MyH (1993). Correlation of isoenzyme polymorphism and Bayoud-disease resistance in date palm cultivars and progeny. Euphytica 65:23-32.

Bonnin I, Prosperi JM, Olivieri I (1996). Genetic markers and quantitative genetic variation in Medicago truncatula (Leguminosae): a comparative analysis of population structure. Genetics 143:1795-1805.

Brown AHD, Weir BS (1983). Measuring genetic variability in plant populations. In: Tanksley SD, Orton TJ (Eds). Isozymes in Plant Genetics and Breeding. Elsevier Science Publishing Co, Amsterdam pp 219-239.

Bullitta S, Floris R, Hayward MD, Loi A, Porqued du C, Veronesi
F (1994). Morphological and biochemical variation in Sardinian populations of Medicago polymorpha L. suitable for rainfed Mediterranean conditions. Euphytica 77:263-268.

Cannon SB, Sterck L, Rombauts S, Sato S, Cheung F, Gouzy J, Wang X, et al. (2006). Legume genome evolution viewed through the Medicago truncatula and Lotus japonicus genomes. Proceeding of the National Academy of Sciences United States of America 103:14959-14964.

Chandra A, Verma S, Pandey KC (2011). Genetic similarity based on isozyme banding pattern among fifty species of Medicago representing eight sections (Fabaceae). Biochemical Systematics and Ecology 39:711-717.

Cherifi K (1996). Polymorphisme enzymatique de quelques populations naturelles de Medicago ciliaris (L.) Krock et de Medicago intertexta (L.) Mill. [Enzymatic polymorphism of some natural populations of Medicago ciliaris (L.) Krock and Medicago intertexta (L.) Mill]. Acta Botanica Gallica 143:155165.

Cherifi K, Boussaid M, Marrakchi M (1993). Diversité génétique de quelques populations naturelles de Medicago ciliaris (L) Krock et de Medicago intertexta (L) Mill. I. Analyse de la variabilité morphologique. [Genetic diversity of some natural populations of Medicago ciliaris (L.) Krock and Medicago intertexta (L.) Mill. I. Morphological variability analysis]. Agronomie 13:895-908.

El Hansali M, Zinelabidine LH, Haddioui A (2007). Variabilité des caractères morphologiques des populations naturelles de Medicago truncatula Gaertn. au Maroc. [Morphological characters variability of some natural populations of Medicago truncatula Gaertn. in Morocco]. Acta Botanica Gallica 154:643-649.

Ferguson ME, Robertson LD (1996). Genetic diversity and taxonomic relationships within the genus Lens as revealed by allozyme polymorphism. Euphytica 91(2):163-172.

Haddioui A, Zinelabidine LH, Nouri M, Ajal EA, El Hansali M, Hanine $H$ (2012). Genetic diversity of natural populations of Medicago truncatula in Morocco using isozyme polymorphism. World Journal of Agricultural Sciences 8:1319.

Hamrick JL, Godt NJ (1990). Allozyme diversity in plant species. In: Brown AHD, Clegg MT, Kahler AL, Weir BS (Eds). Plant population genetics, breeding and genetic ressources. Sinauer Associates Inc, Sunderland pp 43-63.

Hannachi AS, Boussaid M, Marrakchi M (1998). Genetic variability organization and gene flow in natural populations of Medicago polymorpha L. prospected in Tunisia. Genetics Selection Evolution 30:121-135.

Heyn CC (1963). The Annual Species of Medicago. Magnes Press, Jerusalem.

Issolah R, Abdelguerfi A (1999). Variability within 31 spontaneous populations of Trifolium scabrum L., nature of relations with factors of the site of origin. In: Etienne M (Ed). 
IX Meeting of the Fao-Ciheam Sub-Network on Mediterranean Pastures and Fodder Crops. Ciheam-Iamz, Badajoz pp 123-127.

Jaccard P (1908). Nouvelles recherches sur la distribution florale. Bulletin de la Societe Vaudoise des Sciences Naturelles 44:223-270.

Jenczewski E, Prosperi JM, Ronfort J (1999a). Evidence for gene flow between wild and cultivated Medicago sativa (Leguminosae) based on allozyme markers and quantitative traits. American Journal of Botany 86:677-687.

Jenczewski E, Prosperi JM, Ronfort J (1999b). Differentiation between natural and cultivated populations of Medicago sativa (Leguminosae) from Spain: analysis with random amplified polymorphic DNA (RAPD) markers and comparison to allozymes. Molecular Ecology 8:1317-1330.

Kahler AL, Allard RW, Krzakow AM, Wehrhahn CG, Nevo E (1980). Associations between isozyme phenotypes and environment in the slender wild oat (Avena barbata). Theoretical and Applied Genetics 56:31-47.

Kongkiatngam P, Waterway MJ, Fortin MG, Coulman BE (1995). Genetic variation within and between two cultivars of red clover (Trifolium pratense L.): comparisons of morphological, isozyme and RAPD markers. Euphytica 84:237-246.

Lesins KA, Lesins I (1979). Genus Medicago (Leguminosae). A Taxogenetic Study. The Hague, London.

Lewis G, Schrire B, Mackinder B, Lock M (2005). Legumes of the world. Royal Botanic Gardens Kew, UK.

Long AD, Singh AS (1995). Molecules versus morphology: the detection of selection acting on morphological characteristics along a cline in Drosophila melanogaster. Heredity 74:569-581.

Malaviya DR, Roy AK, Kaushal P, Kumar B, Tiwari A (2008). Genetic similarity among Trifolium species based on isozyme banding pattern. Plant Systematics and Evolution, 276(12):125-136.

Mantel N (1967). The detection of disease clustering and a generalized regression approach. Cancer Research 27:209-220.

Paredes M, Becerra V, Rojo C, Del Pozo A, Ovalle C, Aronson J (2002). Ecotypic differentiation in Medicago polymorpha L. along an environmental gradient in central Chile. RAPDs studies show little genetic divergence. Euphytica 123:431-439.

Podolsky RH, Holtsford TP (1995). Population structure of morphological traits in Clarkia dudleyana I. comparison of FST between allozymes and morphological traits. Genetics 140:733-744.

Prosperi JM, Jenczewski E, Angevainand M, Ronfort J (2006). Morphologic and agronomic diversity of wild genetic resources of Medicago sativa L. collected in Spain. Genetic Resources and Crop Evolution 53:843-856.
Quezel P, Santa S (1962). Nouvelle flore de l'Algérie et des régions désertiques méridionales. [New flora of Algeria and the southern desert regions]. CNRS, Paris.

Radwan MS, Alfakhry AK, Al-Hasan AM (1980). Variation between and within species of annual medics from northern Iraq. Egyptian Journal of Agronomy 5:153-159.

Scandalios JG (1969). Genetic control of multiple molecular forms of enzymes in plants: a review. Biochemical Genetics 3:37-79.

Singh NK, Shepherd KW, Cornish GB (1991). A simplified SDSPAGE procedure for separating LMW subunits of glutenin. Journal of Cereal Science 14:203-208.

Small E (2010). Alfalfa and relatives: Evolution and classification of Medicago. NRC Research Press, Canada.

Small E, Jomphe M (1989). A synopsis of the genus Medicago (Leguminosae). Canadian Journal of Botany 67:3260-3294.

Spitze K (1993). Population structure in Daphnia obtusa: quantitative genetic and allozymic variation. Genetics 135:367-374.

Stewart P (1974). Un nouveau climagramme pour l'Algérie et son application au barrage vert. Bulletin de la Société d'histoire naturelle de l'Afrique du nord 65:239-248.

Tucak M, Popović S, Čupić T, Grljušić S, Bolarić S, Kozumplik V (2008). Genetic diversity of alfalfa (Medicago spp.) estimated by molecular markers and morphological characteristics. Periodicum Biologorum 110:243-249.

Valizadeh M, Kang K, Kanno A, Kameya T (1996). Analysis of genetic distance among nine Medicago species by using DNA polymorphism. Breeding Science 46:7-10.

Warwick SI, Black LD (1986). Electrophoretic variation in triazine-resistant and susceptible populations of Amaranthus retroflexus L. New Phytologist 104:661-670.

Weeden NF, Wendel JF (1990). Genetics of plant isozymes, In: Soltis DE, Soltis PE (Eds). Isozymes in Plant Biology. Dioscorides Press, Portland pp 46-72.

Yang RC, Yeh FC, Yanchuk AD (1996). A comparison of isozyme and quantitative genetic variation in Pinus contorta ssp. latifolia by FST. Genetics 142:1045-1052.

Zivković B, Radović J, Sokolović D, 区iler B, Banjanac T, Strbanović R (2012). Assessment of genetic diversity among alfalfa (Medicago sativa L.) genotypes by morphometry, seed storage proteins and RAPD analysis. Industrial Crops and Products 40:285-291. 